\title{
One-hour serum xylose as an absorption test in the tropics
}

\author{
PG HILL, IN ROSS, * R JACOB, S JYOTHEESWARAN, AND VI MATHAN \\ From the Wellcome Research Unit and The Gastroenterology Clinic, Christian Medical College Hospital, \\ Vellore-632 004, India
}

SUMMARY The 1-hour serum xylose (surface area corrected) as an indication of xylose absorption after $5 \mathrm{~g}$ oral $\mathrm{D}$-xylose has been compared with the 5-hour urine excretion test in a tropical population. The study confirmed that the peak serum xylose concentration occurs at 1 hour and that correction to a constant body surface area improves the discrimination between subjects with normal and impaired xylose absorption. The significantly lower reference range for the 1-hour surface area corrected serum xylose $(0 \cdot 55-1 \cdot 11 \mathrm{mmol} / \mathrm{l})$ compared to the UK figure reflects the reduced absorptive capacity of the jejunum, a result of tropical enteropathy. In view of the difficulties in obtaining accurate urine collections in tropical countries, especially in field studies, it is recommended that the 1-hour serum xylose (surface area corrected) should be adopted as the standard test of xylose absorption.

Measurement of $D(+)$ xylose excretion in a timed urine collection after oral administration is the method most widely used to estimate absorption of D-xylose, an index of small bowel function. Delayed gastric emptying, renal disease, and inadequate urine collection are factors that reduce urinary excretion of $D$-xylose, giving a false impression of impaired small intestinal function. ${ }^{12}$ The discrimination of small bowel abnormality has been shown to be better if the concentration of serum xylose is measured 1 hour after ingestion of the oral dose, and is further improved if the measured concentration is corrected for body surface area. ${ }^{3}$ In view of earlier findings ${ }^{4}$ that the pattern of urinary xylose excretion in southern India is different from that in temperate zones, it is necessary to validate the observations of Haeney et al. $^{3}$ for tropical climates. The observed differences between tropical and temperate regions may be related to the prevalence of non-specific tropical enteropathy-the occurrence of structural and possibly functional abnormalities of the small intestinal mucosa in apparently healthy individuals in the tropics. ${ }^{5-8}$

We report the results of a study carried out in southern India of the serum xylose concentration after administration of $5 \mathrm{~g} \mathrm{D}$-xylose orally, validating the applicability of this test in a tropical population.

*Present address: Hope Hospital, Salford, UK.

Accepted for publication 13 August 1980

\section{Subjects studied and methods}

A total of 111 subjects admitted consecutively in a metabolic ward were studied; these included apparently normal volunteers and patients with a variety of diseases associated with malabsorption. Informed consent was obtained from all subjects. Absorption of fat, ${ }^{9} \mathrm{D}$-xylose urinary excretion, ${ }^{4}$ and vitamin $\mathrm{B} 12$ absorption ${ }^{10}$ were tested in all patients. In addition, 1-hour serum samples were obtained after oral xylose from nine healthy laboratory staff from the upper socioeconomic group, who were well nourished and had no gastrointestinal illness. The height and weight of each subject were recorded. D-xylose (5 g)

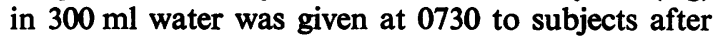
an overnight fast. Solid food was withheld for a further 2 hours, although at least $500 \mathrm{ml}$ of water was given to ensure adequate urine volumes. Urine collection in three timed fractions (0-2, 2.1-5, 5.1-8 hours) and estimation of $\mathrm{D}$-xylose in urine were done as described earlier. 41112

In all subjects, blood samples were collected before (basal) and 1 hour after oral xylose administration. Five millilitres of venous blood was collected on each occasion without anticoagulants, and the serum was separated and stored at $-20^{\circ} \mathrm{C}$ till analysed. Analysis of aliquots of the same frozen sample over a 10-week period did not show significant differences. In each batch an aliquot from a pooled serum sample was used for quality control. 
Serum xylose was measured by ferricyanide reduction in an automated continuous-flow system after destruction of glucose in the sample by glucose oxidase as described by Haeney et al. $^{3}$ Measured serum xylose was expressed as the 1-hour value minus the basal value to correct for non-glucose, non-xylose reducing substances. The measured serum xylose was corrected to a constant surface area of $1.73 \mathrm{~m}^{2}$ as described by Haeney et al. ${ }^{3}$

Full absorption curves were done in 25 subjects, 13 of whom had normal and 12 reduced 5-hour urinary xylose excretion. Venous blood samples were collected before and $\frac{1}{2}, 1,1 \frac{1}{2}, 2,3$, and 4 hours after the administration of xylose.

Urine and blood xylose values were compared in all 111 subjects, who were divided into three groups: group 1, 29 subjects without malabsorption of either fat or vitamin B12; group 2, 68 subjects with fat malabsorption but normal vitamin B12 absorption; and group 3, 14 subjects with malabsorption of both fat and vitamin B12. Renal function, as measured by blood urea and serum creatinine, was normal in all subjects.
Results

The peak serum xylose concentration in 11 of the 13 subjects with normal 5-hour urine excretion was 1 hour after oral administration (Table 1). The remaining two subjects had peak values at $1 \frac{1}{2}$ hours; in both these, the 1-hour value was within the range of those with a peak at 1 hour. Of the 12 subjects with low urine xylose excretion, seven $(58 \%)$ had peak values at 1 hour. A wider spread in the time of appearance of the peak was found in this group (Table 1). In both groups of subjects the highest mean serum concentration was at 1 hour, although

Table 1 Time of peak serum xylose value in normal and abnormal subjects

\begin{tabular}{lllllll}
\hline Subject & & \multicolumn{5}{c}{ Time of peak value (hours) } \\
\cline { 2 - 7 } & $n$ & $\frac{1}{2}$ & 1 & $1 \frac{1}{2}$ & 2 & 3 \\
\hline Normal & 13 & 0 & 11 & 2 & 0 & 0 \\
Abnormal & 12 & 1 & 7 & 1 & 1 & 2 \\
\hline
\end{tabular}

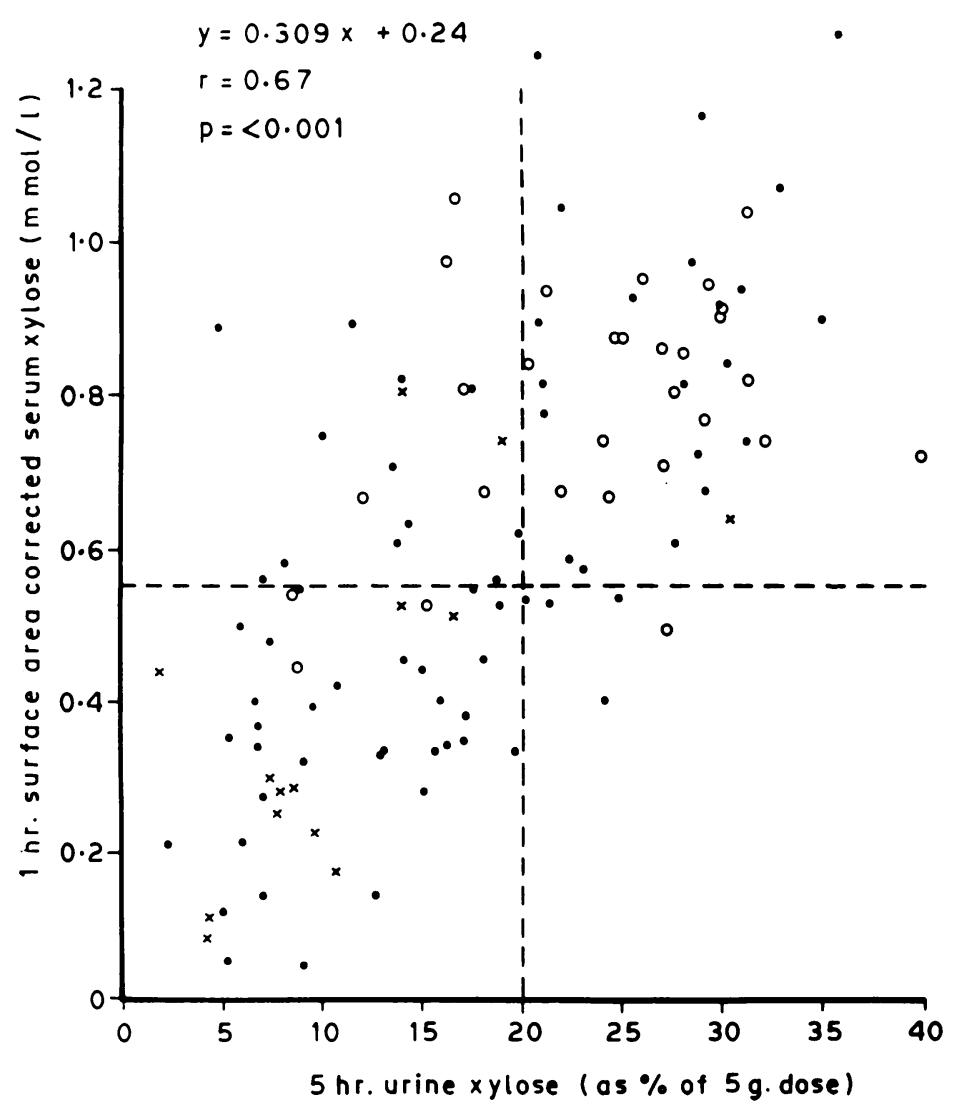

Comparison of 1-hour surface area corrected serum xylose with 5-hour urine xylose excretion after a $5 \mathrm{~g}$ oral dose of $\mathrm{D}-x y$ lose: $\bigcirc$ group 1; group 2; $\mathrm{x}$ group 3. 
Table 2 Discrimination between normal and abnormal subjects at different times after $5 \mathrm{~g}$ xylose

\begin{tabular}{|c|c|c|c|c|c|c|c|}
\hline \multirow[t]{2}{*}{ Subject } & \multirow{2}{*}{$n$} & \multicolumn{4}{|c|}{$\begin{array}{l}\text { Serum xylose }(\mathrm{mmol} / \mathrm{l}) \\
\text { surface area }\end{array}$} & \multicolumn{2}{|c|}{ corrected for } \\
\hline & & $\frac{1}{2} h$ & $I h$ & $1 \frac{1}{2} h$ & $2 h$ & $3 h$ & $4 h$ \\
\hline $\begin{array}{c}\text { Normal } \\
\text { Mean } \\
\text { SD }\end{array}$ & 13 & $\begin{array}{l}0 \cdot 47 \\
0 \cdot 16\end{array}$ & $\begin{array}{l}0.70 \\
0.09\end{array}$ & $\begin{array}{l}0 \cdot 62 \\
0 \cdot 14\end{array}$ & $\begin{array}{l}0.53 \\
0.06\end{array}$ & $\begin{array}{l}0.45 \\
0.09\end{array}$ & $\begin{array}{l}0 \cdot 33 \\
0 \cdot 13\end{array}$ \\
\hline $\begin{array}{l}\text { Abnorma } \\
\text { Mean } \\
\text { SD }\end{array}$ & 12 & $\begin{array}{l}0 \cdot 24 \\
0 \cdot 14\end{array}$ & $\begin{array}{l}0 \cdot 41 \\
0 \cdot 19\end{array}$ & $\begin{array}{l}0 \cdot 39 \\
0 \cdot 16\end{array}$ & $\begin{array}{l}0 \cdot 38 \\
0 \cdot 15\end{array}$ & $\begin{array}{l}0.34 \\
0 \cdot 19\end{array}$ & $\begin{array}{l}0 \cdot 27 \\
0 \cdot 12\end{array}$ \\
\hline$t$ & & $3 \cdot 70$ & $4 \cdot 71$ & 3.75 & $3 \cdot 14$ & 1.89 & $1 \cdot 14$ \\
\hline
\end{tabular}

in the group with abnormal urine xylose excretion the peak was less well defined (Table 2).

Comparison of mean serum values at different times showed that the greatest discrimination between normal and abnormal xylose absorption also occurs at 1 houir $(t=4 \cdot 71)$. The lower limit of normal for the surface area corrected serum xylose was calculated from the values of 21 subjects in group 1 without fat or vitamin B12 malabsorption and with normal 5-hour urine xylose excretion $(>20 \%)$ and of nine members of the laboratory staff. The reference range calculated from these 30 subjects was $0 \cdot 55-1 \cdot 11 \mathrm{mmol} / \mathrm{l}$ (mean $0 \cdot 83$, SD $0 \cdot 14$ $\mathrm{mmol} / \mathrm{l})$.

A good correlation $(r=0.67, P<0.001)$ was shown between the 5-hour urine excretion of xylose and the 1-hour surface area corrected serum xylose in the 111 subjects studied (Figure). In 87 subjects $(78 \%)$ there was concordance between the urine and serum values. In 19, the urine xylose was low with a normal serum value, and these subjects would have been considered to have xylose malabsorption on the basis of the urine result alone. In the remaining five subjects, the urine xylose excretion was normal but the 1-hour surface area corrected serum value $\infty$ was below the lower limit of the reference range.

Correction of the measured serum xylose concentration to a constant body surface area $\left(1.73 \mathrm{~m}^{2}\right) \stackrel{\omega}{\omega}$ narrowed the distribution of results in all three groups of subjects and improved the discrimination of the two groups with impaired xylose absorption + from group 1 (Table 3). The mean 1-hour serum $?$ xylose value is decreased compared to group $1 \vec{V}$ in those patients with steatorrhoea (group 2). It is decreased to a greater extent in group 3, where there was malabsorption of both fat and vitamin B12.

\section{Discussion}

This study confirms that in the population of southern $\infty$ India the peak serum concentration after a $5 \mathrm{~g}$ oral. dose of D-xylose occurs at 1 hour (Tables 1 and 2) and that correction of the measured serum value to a constant body surface area narrows the range of values and improves the discrimination between $\stackrel{2}{\circ}$ those with normal and with abnormal small

Table 3 Discrimination between normal and abnormal subjects

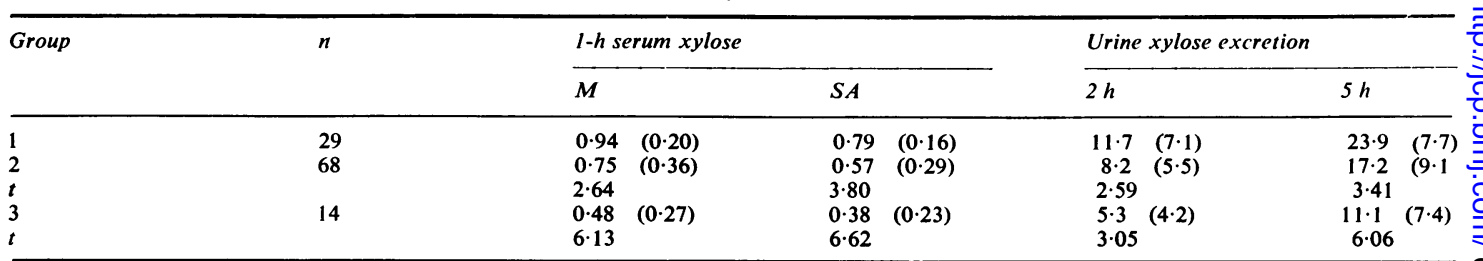

For explanation of groups, see text. Figures indicate mean (SD). $\mathbf{M}=$ measured serum xylose; $\mathbf{S A}=$ surface area corrected serum $\mathrm{xylose}$. Serum xylose is expressed as $\mathrm{mmol} / \mathrm{l}$, urine xylose as $\%$ of $5 \mathrm{~g}$ dose.

Table 4 Comparison of data from south India and from England

\begin{tabular}{|c|c|c|c|c|c|c|c|}
\hline & \multirow[t]{3}{*}{$n$} & \multirow{2}{*}{\multicolumn{2}{|c|}{$5-h$ urine xylose $(\%)$}} & \multicolumn{4}{|c|}{ I-h serum xylose $(\mathrm{mmol} / \mathrm{l})$} \\
\hline & & & & \multicolumn{2}{|c|}{ Measured } & \multicolumn{2}{|c|}{$\begin{array}{l}\text { Surface area } \\
\text { corrected }\end{array}$} \\
\hline & & Mean & $S D$ & Mean & $S D$ & Mean & $S D$ \\
\hline $\begin{array}{l}\text { South India } \\
\text { Baker et al. }\end{array}$ & 49 & $28 \cdot 2$ & $9 \cdot 1$ & - & & - & \\
\hline $\begin{array}{l}\text { This study } \\
\text { England }\end{array}$ & 21 & $27 \cdot 6$ & 4.9 & 0.97 & $0 \cdot 18$ & $0 \cdot 81$ & $0 \cdot 12$ \\
\hline Sammons et al. ${ }^{13}$ & 29 & $35 \cdot 7$ & $7 \cdot 1$ & - & & 一 & \\
\hline $\begin{array}{l}\text { Haeney et al. }{ }_{t}^{3} \\
\end{array}$ & 130 & $35 \cdot 0$ & $9 \cdot 2$ & $\begin{array}{l}1 \cdot 03 \\
1 \cdot 22\end{array}$ & $0 \cdot 21$ & $\begin{array}{l}0 \cdot 94 \\
3 \cdot 18\end{array}$ & $0 \cdot 18$ \\
\hline
\end{tabular}


intestinal function (Table 3). While these observations are in agreement with those of Haeney et $a .^{3}$ the range and mean value of the 1-hour surface area corrected serum xylose is significantly lower than that of a normal population in the UK (Table 4).

The mean measured 1-hour serum xylose concentration of our population was not significantly lower than that observed in the UK (Table 4), but, in general, body height and weight are less in southern India than in the UK, so that after correction to a constant surface area the mean serum concentration of control subjects was significantly lower $(P<0.005)$, indicating that the amount of xylose absorbed by our controls was less than that absorbed by subjects in the UK study. This is confirmed by the lower 5-hour urine xylose excretion in our subjects (Table 4). Non-specific tropical enteropathy is known to be widely prevalent in the asymptomatic population of southern India ${ }^{6}$ as in many other tropical developing countries. Non-specific tropical enteropathy is characterised by the occurrence of small bowel mucosal morphological abnormalities, ${ }^{5}$ which are detectable even at the ultrastructural level, ${ }^{14}$ low urinary xylose excretion, ${ }^{4}$ and reduced absorptive capacity of the jejunum in perfusion studies. ${ }^{8} 15$ The significance of this 'lesion' is not known, but the available evidence suggests that non-specific tropical enteropathy may be the response of the small bowel mucosa to the environment, especially bacterial, viral, and parasitic agents, as well as dietary constituents that are as yet unidentified. ${ }^{6}$ Since all healthy southern Indian volunteers who have been biopsied so far show mucosal morphological evidence of non-specific tropical enteropathy, we conclude that the reduced absorption of D-xylose demonstrated here is a functional counterpart of the morphological lesion.

In $87(78 \%)$ of the 111 subjects in whom urine and serum xylose levels were compared, the two tests were in concordance. In 19 subjects the 5-hour urine xylose was low but the 1-hour surface area corrected serum xylose was above $0.55 \mathrm{mmol} / \mathrm{l}$. Careful analysis of these patients' records showed that, in 11 of them, incomplete bladder emptying at 5 hours, low urine volumes, or decreased clearance with old age were responsible for the discordant results. In a further two patients, the 5-hour urine xylose excretion was $11.4 \%$ and $13.5 \%$ with 1 -hour surface area corrected serum concentrations of 0.89 and $0.71 \mathrm{mmol} / 1$, respectively. For both patients, blood urea and serum creatinine values were at the upper limit of normal, and it is likely that their urine results reflect the sensitivity of the test to minimal impairment of renal clearance, as observed in the elderly. ${ }^{23}$ One patient with 5-hour urine xylose of $19.8 \%$ and a serum level of $0.62 \mathrm{mmol} / \mathrm{l}$ had ascites. In the remaining five of the 19 patients, no explanation for the apparently low urine results could be found, but incomplete urine collection, inspite of the supervision of the metabolic ward staff, is the most likely reason for these discordant results.

In five patients, the 5-hour urine xylose excretion was normal but the 1-hour surface area corrected serum xylose was less than $0.55 \mathrm{mmol} / 1$. Three of them had borderline serum values $(0.53 \mathrm{mmol} / \mathrm{l})$, leaving two patients who appeared to have a genuine discrepancy between the serum and urine values.

The correlation coefficient of 0.67 indicates a highly significant correlation between the two methods of assessing xylose absorption ( $\mathrm{P}<0.001)$, which would have been better if the discordant results due to low urine values had been excluded. In view of the difficulties of obtaining accurate 5-hour urine collections, especially in the tropics and in field studies, it is recommended that the 1-hour serum xylose (surface area corrected) after $5 \mathrm{~g}$ oral D-xylose should be adopted as a routine test in the investigation of intestinal function. Further methodological studies are being undertaken to overcome, if possible, the need for a basal sample and the requirement of an automated system to achieve the required precision.

INR was in receipt of a special grant from the Wellcome Trust. The work of the Wellcome Research Unit is supported by the Wellcome Trust, London.

\section{References}

${ }^{1}$ Sladen GE, Kumar PJ. Is the xylose test still a worthwhile investigation? $\mathrm{Br}$ Med $J$ 1973;3:223-5.

${ }^{2}$ Kendall MJ. The influence of age on the xylose absorption test. Gut 1970;11:498-501.

${ }^{3}$ Haeney MR, Culank LS, Montgomery RD, Sammons HG. Evaluation of xylose absorption as measured in blood and urine: a one-hour blood xylose screening test in malabsorption. Gastroenterology 1978;75:393-400.

${ }^{4}$ Baker SJ, Jacob R, Mathan VI. An evaluation of the $5 \mathrm{~g}$ D-xylose absorption test, with fractional urine collections in subjects living in southern India. Indian J Med Res $1971 ; 59: 1869-77$.

${ }^{5}$ Baker SJ, Ignatius M, Mathan VI, Vaish SK, Chacko CC. Intestinal biopsy in tropical sprue. In: Wolstenholme GEW, Cameron MP, eds. Intestinal biopsy. London: Churchill, 1962;84.

- Baker SJ, Mathan VI. Tropical enteropathy and tropical sprue. Am J Clin Nutr 1972;25:1047-55.

' Baker SJ. Geographical variations in the morphology of the small intestinal mucosa in apparently healthy individuals. Pathol Microbiol 1973;39:222-37.

${ }^{8}$ Hellier MD, Radhakrishnan AN, Ganapathy V, Gammon A, Baker SJ. Intestinal absorption in normal Indian and English people. $\mathrm{Br}$ Med $J$ 1976;1:186-8.

$\checkmark$ Van De Kamer JH, Huinink Ten BH, Weyers HA. Rapid method for the determination of fat in faeces. $J$ Biol Chem 1949;177:347-55. 
${ }^{10}$ Mathan VI, Swarnabai S, Baker SJ. Intestinal absorption of radioactive vitamin B12: a comparison of plasma, faecal and urinary tests. Indian J Med Res 1973;61: 714-23.

${ }^{11}$ Roe JH, Rice EW. A photometric method for the determination of free pentoses in animal tissues. $J$ Biol Chem 1948;173:507-12.

12 Goodhart JM, Kingston GR. Modification of the method for the estimation of xylose in urine. J Clin Pathol $1968 ; 22: 621-2$.

${ }^{13}$ Sammons HG, Morgan DB, Frazer AC, Montgomery RD, Philip WM, Phillips MJ. Modification of the xylose absorption test as an index of intestinal function. Gut
1967;8:348-53.

${ }^{14}$ Mathan M, Mathan VI, Baker SJ. An electron-microscopic study of jejunal mucosal morphology in control subjects and in patients with tropical sprue in southern India. Gastroenterology 1975;68:17-32.

15 Hellier MD, Radhakrishnan AN, Ganapathy V, Mathan VI, Baker SJ. Intestinal perfusion studies in tropical sprue. Gut 1976;17:511-6.

Requests for reprints to: Dr VI Mathan, Wellcome Research Unit, Christian Medical College Hospital, Vellore 632 004, India. 